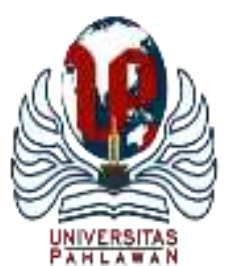

\title{
JURNALBASICEDU
}

Volume 5 Nomor 6 Tahun 2021 Halaman 6418 - 6425

Research \& Learningin Elementary Education

https://jbasic.org/index.php/basicedu

\section{Pembudayaan Nilai-Nilai Islam di Madrasah dan Masyarakat}

\author{
Sedya Santosa ${ }^{1}$, Tria Marvida ${ }^{2}$
}

Universitas Islam Negeri Sunan Kalijaga Yogyakarta, Indonesia ${ }^{1,2}$

E-mail: sedya.santosa@uin-suka.ac.id 1 ,20204082012@ student.uin-suka.ac.id ${ }^{2}$

\begin{abstract}
Abstrak
Bagi umat Islam, tujuan pendidikan yang dirumuskan di tingkat nasional adalah sesuatu yang istimewa, di mana iman dan taqwa yang merupakan tujuan pendidikan dalam Islam dijadikan sebagai tujuan pendidikan nasional. Untuk mewujudkan tujuan pendidikan tersebut, maka pendidikan harus mampu menanamkan nilainilai Islam pada siswa. Pembudayaan nilai-nilai Islam di lingkungan madrasah dan masyarakat dinilai mampu untuk mewujudkan tujuan dari pendidikan Islam itu sendiri. Selain lingkungan madrasah, lingkungan masyarakat juga berperan dalam menanamkan nilai-nilai Islam pada diri siswa. Tulisan ini menggunakan penelitian kualitatif. Adapun jenis penelitian kualitatif yang digunakan adalah library research. Teknik pengumpulan data yang digunakan yaitu dokementasi. Sedangkan teknik analisis data menggunakan model Miles dan Huberman, antara lain: reduksi data, display data dan gambaran konklusi atau verifikasi. Berdasarkan hasil kajian dapat diketahui bahwa nilai-nilai normatif dalam ajaran Islam terkandung dalam AlQur'an yang menjadi acuan dalam pendidikan Islam. Nilai-nilai ini termasuk akidah, ibadah, dan akhlak. Adapun strategi yang digunakan dalam melaksanakan pembudayaan nilai-nila Islam baik di madrasah ataupun masyarakat adalah: strategi keteladanan, pembiasaan, ibrah dan amtsal, pemberian nasehat, pemberian janji dan ancaman, kedisiplinan, kekuasaan, persuasi, dan peraturan pendidikan.
\end{abstract}

Kata Kunci: Nilai-nilai Islam, madrasah, masyarakat.

\begin{abstract}
For Muslims, the educational goals formulated nationally are something special, where faith and piety, which are the goals of education in Islam, are used as national education goals. To realize these educational goals, education must be able to instill Islamic values in students. Cultivating Islamic values in the madrasa environment and society is considered capable of realizing the goals of Islamic education itself. In addition to the madrasa environment, the community environment also plays a role in instilling Islamic values in students. This paper uses qualitative research. The type of qualitative research used is library research. The data collection technique used is documentation. Meanwhile, the data analysis technique uses the Miles and Huberman model, including: data reduction, data display and conclusion drawing or verification. Based on the results of the study, it can be seen that the normative values in Islamic teachings are contained in the Qur'an which is the reference in Islamic education. These values include aspects of faith, worship, and morals. The strategies used in implementing the culture of Islamic values both in madrasas and in the community are: exemplary strategies, habituation, ibrah and proverbs, giving advice, giving promises and threats, discipline, power, persuasion, and educational regulations.
\end{abstract}

Keywords: Islamic values, madrassas, society

Copyright (c) 2021 Sedya Santosa, Tria Marvida

$\triangle$ Corresponding author :

Email : 20204082012@student.uin-suka.ac.id

DOI : https://doi.org/10.31004/basicedu.v5i6.1643

ISSN 2580-3735 (Media Cetak)

ISSN 2580-1147 (Media Online) 


\section{PENDAHULUAN}

Globalisasi telah merubah seluruh aspek di masyarakat. Hal ini termasuk pula dalam pendidikan. Berbagai aspek perubahan dalam pendidikan dipengaruhi melalui ilmu pendidikan modern, perkembangan ilmu pengetahuan alam dan teknologi, serta akibat sosial itu sendiri. (Munif, t.t., 47) Pendidikan adalah bagian yang tidak terpisahkan dari manusia. Di mana ada manusia, maka disana pula ada pendidikan. Manusia membutuhkan pendidikan untuk melanjutkan hidup dan mencapai tujuan hidup.

Tujuan pendidikan yang dirumuskan di tingkat nasional adalah sesuatu yang istimewa bagi umat Islam, dikarenakan iman dan dan taqwa yang merupakan tujuan pendidikan Islam ditetapkan sebagai tujuan pendidikan nasional. Dalam Islam, membentuk kepribadian Islam yang utuh, yaitu manusia ideal yang terdiri dari aspek pribadi, sosial dan intelektual. Seluruh pribadi berdasarkan iman dan kesalehan, khusyuk dan rasa malu (Talibo 2019, 49).

Untuk mencapai tujuan pendidikan tersebut, pendidikan harus mampu menanamkan nilai-nilai Islam pada siswa. Pembudayaan nilai-nilai Islam di lingkungan madrasah dan masyarakat dinilai mampu untuk mewujudkan tujuan dari pendidikan Islam itu sendiri. Selain lingkungan madrasah, lingkungan masyarakat juga berperan dalam menanamkan nilai-nilai Islam pada diri siswa.

Pendidikan pada hakekatnya adalah proses pembentukan moral masyarakat madani, masyarakat yang berwatak manusia dan berwajah manusia. Artinya, pendidikan yang dimaksud di sini bukan sekedar sekolah (education is not just school education) melainkan pendidikan sebagai jejaring sosial (education as community networks). Pendidikan harus memberikan konstribusi positif bagi pembentukan seseorang dengan keseimbangan antara kemampuan intelektual dan moral.

Pendidikan akhlak menjadi sangat penting untuk stabilitas dan keutuhan suatu bangsa. Pendidikan akhlak bertujuan untuk mengubah manusia menjadi berintelktual dan spiritual untuk meningkatkan kualitas hidup. Pendidikan akhlak dapat diterapkan melalui pembudayaan nilai-nilai Islam di sekolah atau madrasah.(Siswanto 2019, 51-52).

Steeman mengatakan bahwa nilai adalah sesuatu yang memberikan makna hidup, yang memberikan referensi, titik awal, dan tujuan hidup. Nilai adalah sesuatu yang dipelihara yang dapat mewarnai dan meramaikan tindakan seseorang. Nilai bukan sekedar keyakinan, nilai selalu dikaitkan dengan pola pikir dan tindakan, sehingga terdapat hubungan yang sangat erat antara nilai dan etika.

Nilai tidak sama bagi semua anggota masyarakat karena kelompok sosial ekonomi, politik, agama, suku, budaya dan invidu yang berbeda seringkali kelompok tersebut memiliki nilai yang berbeda. Dalam Islam nilai terbagi atas dua, pertama nilai yang diturunkan dari Allah SWT, kedua nilai yang dibentuk oleh manusia.

Dengan demikian, kedua nilai ini membentuk norma atau aturan hidup yang diterima dan dilembagakan dalam masyarakat. Sebagai seorang hamba, manusia memiliki kewajiban untuk memahami, menghayati, mengamalkan, dan menjunjung tinggi nilai-nilai yang diyakininya.

Nilai-nilai ajaran Islam mengajarkan setiap pemeluknya untuk seimbang, yaitu memperhatikan kebutuhan hidup di dunia, di masa depan, fisik dan mental, spiritual dan material, demokrasi, toleransi (tasamuh), umat (memperlakukan orang dalam batas kemampuannya), kesetaraan (kesetaraan manusia di hadapan Tuhannya), kejujuran, keadilan, ketegasan, beroritentasi pada kualitas, terbuka dan selektif menerima pendapat dari mana-mana (Al-Qur'an dan Sunnah), menghargai waktu, pekerjaan yang produktif dan positif, terencana dan berdasarkan penelitian, modern, inovatif, kreatif, menerima perubahan, menumbuhkan persaudaraan dan persahabatan dengan orang lain, rasional (dapat diterima), sesuai dengan kondisi lingkungan. Waktu dan tempat, dapat dipercaya dan bertanggung jawab atas semua tindakan (Mardia 2017, $60-61)$.

Sekolah adalah lembaga pendidikan yang mencakup lingkungan sosial individu agar dapat berkembang secara interpersonal. (Arifin, t.t., 2) Sebagai lembaga pendidikan Islam, madrasah telah memberikan 
kontribusi yang sangat besar bagi mencerdaskan kehidupan bangsa dan negaraa Indonesia. Sejak awal berdirinya, madrasah telah memberikan pencerahan dan kecerdasan dalam mendidik generasi bangsa muslim yang cerdas, khususnya di bidang keagamaan. Kedatangan rombongan ulama merupakan perpaduan sempurna antara pendidikan madrasah, sehingga professional keagamaan berkembang pesat di Nusantara (Zainuddin 2019, 19). Berdasarkan hal tersebut, madrasah merupakan lembaga pendidikan yang sangat penting dalam menghadapi fenomena krisis moral dengan cara menanamkan budaya ideal, salah satunya dengan cara menanamkan budaya Islami (Mulyadi 2018, 3).

Nilai yang dikembangkan di madrasah tentunya tidak lepas dari peran madrasah sebagai lembaga pendidikan yang bergerak dalam pengembangan, pemeliharaan dan transmisi kegiatan nilai budaya kepada siswanya (Mala 2015, 1). Pembudayaan nilai-nilai Islam di lingkungan madrasah dan masyarakat dapat dilakukan pula dengan berbagai pendekatan ataupun metode. Penggunaan pendekatan ataupun metode ini diharapkan mampu menanamkan nilai-nilai Islam dapat membentuk karakter yang baik (Rizal dan Munip 2017, 48). Pendidikan karakter sendiri adalah entitas dari adanya keberagaman nilai-nilai yang dijunjung dalam masyarakat. Karakter yang melekat pada pola tingkah laku setiap anak akan tercermin dalam kehidupan. Dengan adanya pembudayaan nilai-nilai Islam di madrasah akan membentuk karakter yang berkualitas yang tidak mengabaikan nilai-nilai Islam.

Berdasarkan nilai-nilai Islam yang sempurna, untuk mengembalikan pengetahuan, pemahaman dan perilaku agama untuk menciptakan kerukunan dan kerendahan hati dalam kehidupan beragama, perlu mendidik karakter berdasarkan nilai-nilai Islam sebagai model pemberdayaan moralitas (Muhsinin 2013, 208).

Afni Ma'rufah, "Pengembangan Mata Pelajaran Pendidikan Agama Islam Dalam Mewujudkan Budaya Religius Di Sekolah" pada tahun 2020. Hasil penelitian menunjukkan bahwa budaya keagamaan di SD Muhammadiyah Terpadu dan SD Maarif Ponorogo yaitu shalat dhuha, senyum, shalat, berjabat tangan, toleransi, shalat, dzikir, tadarus Al-Qur'an, istighosah dan shalat berjamaah (Ma'rufah 2020, 125).

Jito Subianto, dalam penelitian tahun 2013 "Peran Keluarga, Sekolah, dan Masyarakat Dalam Pembentukan Karakter Berkualitas". Kesimpulan penelitian ini menunjukkan bahwa dengan masing-masing peran yang dimainkan keluarga, sekolah, dan masyarakat dengan baik dalam memperkuat dan melengkapi pendidikan di antara ketiga pusat tersebut, terdapat peluang besar untuk mencapai sumber daya manusia yang berkualitas (Subianto 2013, 352).

Elvi Wahyudi, "Pembudayaan Nilai-nilai Pendidikan Agama Islam Multikultural Pada Akademik Keperawatan Pemerintah Kabupaten Gresik" pada tahun 2020. Implikasi hasil penelitian ini berkaitan dengan toeri nilai pedidikan agama Islam multicultural dalam dunia keperawatan, selain itu juga berimplikasi praktis bagi Akademi Keperawatan Pemerintah Kabupaten Gresik dalam rangka advokasi berbagai mahasiswa dalam persiapan menghadapi profesi (Wahyudi 2020, 142).

Abdul Kholiq "Pendidikan Agama Islam Dalam Kebudayaan Masyarakat Kalang” tahun 2015. Hasil penelitian menjelaskan terdapat tiga respon masyarakat Kalang terhadap nilai-nilai yang baru muncul (Kholiq 2015, 327)

Berdasarkan uraian di atas, maka dalam tulisan ini penulis akan membahas mengenai pembudayaan nilai-nilai Islam di madrasah dan masyarakat.

\section{METODE PENELITIAN}

Artikel ini menggunakan penelitian kualitatif. Penelitian kualitatif adalah proses penelitian yang menggunakan data beruapa kata-kata tertulis atau lisan dari orang dan pelaku yang dapat diamati. Creswell menjelaskan bahwa dalam penelitian kualitatif, pengetahuan dibangun dengan menafsirkan konstribusi semua peserta penelitian, bukan hanya peneliti (Muh. Fitrah dan Luthfiyah 2017, 44).

Penelitian kualitatif yang digunakan adalah penelitian kepustakaan. Disebut peneitian kepustakaan karena data atau bahan yang diperlukan untuk melengkapi penelitian berasal dari perpustakaan berupa buku, 
ensiklopedia, kamus, majalah, dokumen, esai, dan lain-lain (Harahap 2014, 68). Sugiyono menjelaskan bahwa penelitian kepustakaan adalah studi teoritis, referensi dan literature akademis lainnya tentang budaya, nilai dan norma yang dikembangkan dalam situasi sosial yang diteliti (Sari 2020, 43).

Ciri-ciri penelitian kepustakaan adalah: Pertama, peneliti berhadapan langsung dengan teks atau data numeric dan bukan dengan pengetahuan langsung praktik kontemporer atau saksi. Kedua, data di perpustakaan "out of the box". Ketiga, data perpustakaan umumnya merupakan sumber sekunder. Keempat, keadaan data perpustakaan tidak dibatasi oleh ruang atau waktu (Zed 2008, 4-5).

Teknik pengumpulan data yang digunakan adalah dokementasi. Mirzaqon dan Purwoko menjelaskan bahwa dokumentasi mencari data tengtang hal-hal atau variabel yang berupa catatan, buku, karangan atau artikel, majalah, dan lain-lain. Sedangkan teknik analisis data menggunakan model Miles dan Huberman, yang meliputi: reduksi data, display data dan gambaran konklusi atau verifikasi (Sari 2020, 48).

\section{HASIL DAN PEMBAHASAN}

\section{Penanaman Nilai-nilai Islam}

Nilai berasal dari bahasa Latin vale're yang berarti berguna, mampu, berdaya, berlaku, dimana nilai diartikan sebagai sesuatu yang baik, berguna paling sedikit menurut kepercayaan seseorang atau sekelompok orang. Nilai merupakan kualitas sesuatu yang membuatnya dihargai, diinginkan, dicari, berharga, berguna dan dapat meghidupkannya dengan bermartabat. Nilai tidak sama bagi semua anggota masyarakat, karena dalam suatu masyarakat itu ada kelompok sosial-ekonomi, politik, agama, etnis dan budaya yang berbeda dan kelompok yang berbeda umunya memiliki sistem nilai yang berbeda (Mardia 2017, 60).

Nilai memainkan peran penting dalam studi perilaku organisasi, karena mereka membentuk dasar untuk memahami sikap dan motivasi kita dan memengaruhi perseppsi kita. Orang-orang bergabung dengan organisasi dengan gagasan yang terbentuk sebelumnya tentang apa yang "seharusnya" dan "tidak seharusnya". Robbins (Zainuddin 2019, 24).

Mujib dan Mudzakkir mengungkapkan nilai-nilai normatif dalam ajaran Islam meliputi tiga pilar utama, yaitu: 1) I'tiqadiyyah, terkait dengan pendidikan keimanan dengan tujuan mengatur keyakinan individu. 2) Khuluqiyyah, berkaitan dengan pendidikan akhlak, bertujuan untuk menghindari perilaku yang rendah dan menghiasi dirinya dengan pujian atas perilaku terpuji. 3) Amaliyyah, yang mengacu pada pendidikan perilaku sehari-hari, baik pendidikan ibadah maupun pendidikan muamalah.

Nata mengungkapkan, nilai ajaran Islam dalam pendidikan Islam meliputi aspek akidah, ibadah, dan akhlak. Aspek-aspek tersebut adalah sebagai berikut: (Mardia 2017, 61)

\section{a. Akidah}

Kata Aqidah berasal dari bahasa Arab yaitu aqada-yaqidu, aqdam, yang berarti sesuatu seperti menumpuk atau menguatkan. Jadi Endang Syarifuddin mengatakan bahwa akidah adalah sesuatu yang harus diyakini. Abdurrahman An-Nawawi menambahkan bahwa akidah merupayakan dasar yang digunakan oleh para guru dan akademisi dalam membangun pendidikan Islam.

Berdasarkan penjelasan tersebut, nilai keimanan hendaknya ditanamkan kepada peserta didik tidak hanya melalui pembelajaran tetapi juga diterapkan dalam kehidupan, sehingga anak-anak, di bawah bimbingan iman, diharapkan selalu dapat mengontrol perilakunya dalam segala hal.(Rosidah 2019, 20)

Akidah dalam syariat Islam meliputi kepercayaan kepada hati Allah dan bahwa Nabi Muhammad sebagai Rasul-Nya. Akidah yang demikian berarti bahwa orang-orang yang beriman tidak dalam hati atau perbuatan, tetapi secara kolektif menggambarkan kepercayaan kepada Allah. Artinya, tidak ada niat, perkataan atau perbuatan yang diungkapan oleh seorang mukmin kecuali yang sesuai dengan kehendak dan perinrah Allah SWT. serta dilandasi oleh ketaatan kepada-Nya. Dilakukan siswa agar kegiatan tersebut memiliki nilai ibadah. Akidah Islam bukan hanya sekedar keyakinan dalam hati, tetapi kemudian harus 
menjadi acuan fundamental dalam perilaku dan tindakan, yang pada gilirannya mengarah pada perbuatan baik.(Mardia 2017, 62)

\section{b. Ibadah}

Ibadah adalah bentuk ketaatan kepada Allah. Ibadah merupakan kegiatan wajib bagi setiap muslim yang merupakan bagian dari iman. Ibadah yang dimaksud adalah ibadah yang dijelaskan dalam AL-Qur'an. Isi ibadah dalam pendidikan Islam didasarkan pada bagaimana manusia dapat melakukkan hal-hal berikut: 1) Menjaga hubungan dengan Allah. 2) Menjaga hubungan dengan manusia lain. 3) Kemampuan untuk mempertahankan diri sendiri.

Ibadah merupakan ajaran Islam yang tidak dapat dipisahkan dari iman, karena ibadah merupakan salah satu bentuk perwujudan dari iman itu sendiri. Oleh karena itu, kegiatan ibadah seseorang ditentkan oleh keimanannya. Semakin besar ibadah seseorang, semakin besar pula keyakinannya.(Rosidah 2019, 21)

Ibadah terdiri atas dua hal, yaitu ibadah umum dan khusus. Ibadah umum adalah semua yang Allah izinkan. Ibadah khusus adalah semua yang Allah tetapkan dalam semua detail, derajat, dan cara spesifiknya. Ibadah dalam dalam ajaran Islam sesuai dengan tugas penciptaan manusia, yaitu makhluk yang diperintahkan untuk beribadah kepada Allah merupakan tanda kedamaian dan keamanan bagi semua hamba yang menyembahnya.

\section{c. Akhlak}

Akhlak adalah kekuatan yang telah berkembang bagitu banyak dalam jiwa seseorang sehingga mereka data dengan mudah memulai tindakan tanpa berpikir ulang. Akhlak yang dan buruk merupakan salah satu dari syarat kesempurnaan atau kekurangan iman bagi siswa. Akhlak yang baik adalah yang sesuai dengan ajaran Islam.(Mardia 2017, 62)

Akhlak merupakan isu penting dalam kehidupan manusia. Akhlak merupakan standar yang menentukan kualitas pribadi manusia. Dalam Islam, akhlak ditentukan oleh Al-Qur'an dan hadist. Dikarenakan hal itu, Islam tidak menganjurkan manusia untuk menetapkan standar akhlak secara mendiri.

Menurut Omar Mohammad Al-Toumy al-Syaibany menjelaskan akhlak tidak terbatas pada individu tetapi juga pada masyarakat. Adapun akhlak itu sendiri atas: 1) Irsyad, yaitu kemampuan membedakan perbuatan baik dan buruk. 2) Taufiq, yaitu perbuatan yang sesuai dengan tuntutan Nabi Muhammad SAW. 3) Hidayah, yaitu melakukan pekerjaan yang baik dan terpuji dan menghindari hal-hal yang buruk dan tercela (Rosidah 2019, 22-23).

Pembudayaan nilai-nilai Islami dapat dijelaskan sebagai usaha penanaman nilai-nilai Islam yang sesuai aturan dalam kegiatan madrasah. Quraish Syihab menyatakan bahwa pendidikan Islam bertujuan untuk menuntun manusia maupun kelompok agar dapat menjalankan hidupnya sesuai dengan ajaran Islam.

Yang termasuk bagian dari budaya Islami dalam suatu madrasah diantaranya adalah: 1) Berpakaian Islami. 2) Shalat berjamaah. 3) Dzikir secara bersama-sama. 4) Tadarus/membaca Al-Qur'an. 5) Menebar ukhuwah melalui kebiasaan berkomunikasi secara Islami (senyum, salam dan sapa). 6) Membiasakan adab yang baik. 7) Menyediakan sarana pendidikan yang diperlukan dalam menunjang terciptanya ciri khas agama Islam. Sarana pendidikan tersebut antara lain: a) Mushalla/masjid b) Perpustakaan yang dilengkapi dengan buku-buku dari berbagai disiplin, khususnya mengenal ke-Islaman, c) Terpasangnya kaligrafi ayat-ayat dan hadist Nabi, d) Suasana sekolah yang bersih, tertib, indah dan aman, e) Organisasi yang dapat mengembangkan bakat dan minat siswa. 8) Melakukan berbagai kegiatan yang dapat mencerminkan suasana keagamaan, berupa: a) Doa' bersama, b) Tadarus Al-Qur'an, c) Shalat dzuhur berjama'ah dan kultum, d) Mengisi peringatan hari-hari besar keagamaan, e) Mengintegtrasikan praktik beribadah, baik ibadah mahdhah maupun ibada sosial, f) Melengkapi bahan kajian mata pelajaran umum dengan nuansa keislaman yang relevan.(Mala 2015, 6-9) 9) Kedisiplinan. 10) Kesopanan dalam bertutur kata. 11) Tanggung jawab. 12) 
Kepedulian sosial.(Pairin 2019, 41-44) 13) Budaya Juma't sehat, misalnya gotong royong. 14) Budaya ayo beramal. 15) Budaya ayo berdoa'. 16) Budaya tata tertib kelas. 17) Budaya istighoosah (Rizal 2017, 55-56).

\section{Strategi Penanaman Nilai-nilai Islam di Madrasah dan Masyarakat}

Madrasah merupakan salah satu bentuk lembaga pendidikan Islam yang memiliki sejarah panjang, diawali dengan pendidikan yang sangat tradisional yang dilakukan dalam upaya penyebaran Dakwah Islamiyah dalam penyebaran agama Islam (Zainuddin 2019, 22). Budaya madrasah merupakan perpaduan nilai yang menjadi pedoman dalam berprilaku di madrasah. Oleh karena itu, budaya madrasah harus dikelola dengan baik agar tujuan pembelajaran dapat tercapai (Mala 2015, 9).

Secara umum istilah masyarakat adalah sekelompok individu/orang yang hidup bersama, masyarakat disebut "society" yang berarti interaksi sosial, perubahan sosial dan rasa persatuan, itu berasak dari kata Latin socius, yang berarti teman. Istilah masyarakat berasal dari bahasa Arab syarakah yang berarti sesuatu seperti berpartisipasi. Dengan kata lain, konsep masyarakat adalah suatu struktur yang terkena ketegangan organisasi dan perkembangan akibat konflik antara kelompok-kelompok ekonomi yang terbagi. Menurut Emil Durkheim, masyarakat adalah suatu realitas objektif, mendiri, bebas dari individu-individu yang menyusunnya, masyarakat sebagai kumpulan orang-orang yang telah lama hidup bersama dan sadar akan kesatuan dan koeksistensinya (Prasetyo dan Irwansyah 2020, 164).

Strategi penanaman pembudayaan nilai-nilai Islam yang biasanya digunakan di kalangan praktisi pendidikan meliputi:

\section{a. Strategi Keteladanan (Modeling)}

Keteladanan telah ada dari sejak zaman Rasulullah SAW. keteladanan memiliki peran penting dalam pendidikan Islam karena dapat menunjukkan secara langsung perilaku yang baik kepada siswa. Dalam pendidikan, contoh-contoh ini dihargai, karena siswa secara khusus mengamati perilaku, karena siswa secara khusus mengamati perilaku seorang guru. Melalui strategi keteladanan ini, pendidik dapat secara langsung menunjukkan perilaku yang baik dalam pembelajaran. Perilaku seperti ketakwaan, jujur, ikhlas, dan tanggung jawab yang ditanamkan kepada siswa merupakan sesuatu yang tersembunyi dalam kurikulum (Munif 2017, 7).

Strategi keteladanan dapat dibagi menjadi pemodelan internal dan pemodelan eksternal. Pemodelan internal dapat dilakukan dengan memberikan conoth dari pendidik itu sendiri dalam proses pembelajaran. Sedangkan keteladanan luar dapat dilakukan dengan memberikan contoh figur teladan yang baik. Tokohtokoh lokal dan internasional, seperti penyajian kisah-kisah tokoh agama yang dapat dijadikan panutan. Contoh internal yang guru berikan misalnya dilakukan dengan memulai dan mengakhiri pembelajaran dengan megajar melalui doa', guru datang tepat waktu, membersihkan kelas dan sebagainya (Masriafatin 2019, 30).

\section{b. Strategi Pembiasaan}

Kebiasaan merupakan tindakan yang dilakukan secara berulang-ulang. Pembelajaran melalui strategi pembiasaan adalah pembelajaran yang membiasakan siswa untuk melakukan suatu hal setiap harinya. Strategi pembiasaan ini efektif untuk mengajar siswa, karena ketika siswa mulai terbiasa dengan melakukan hal yang baik maka hal ini akan tercermin dalam kehidupan.

\section{c. Strategi Ibrah dan Amtsal}

Ibrah (mengambil pelajaran) dan Amtsal (perumpamaan) adalah mengambil makna dari berbagai keteladan cerita, fenomena, dan suatu peristiwa. Melalui strategi ini, diharapkan siswa dapat mengambil pelajaran terhadap suatu hal yang terjadi. Abd Tujuan dari strategi ini adalah untuk memberikan kepuasan berpikir tentang masalah keagamaan yang dapat menggerakan, mendidik, atau memperkuat perasaan keagamaan siswa. 


\section{d. Strategi Pemberian Nasehat}

Rasyid Ridha menjelaskan bahwa nasehat adalah peringatan atas kebaikan dan kebenaran melalui cara yang dapat menyentuh hati. Nasehat harus mengandung kalimat yang sopan santun, memotivasi, peringatan atas dosa-dosa.

\section{e. Strategi Pemberian Janji dan Ancaman (Targhib wa tarhib)}

Targhib adalah janji yang diikuti dengan bujukan agar membuat senang terhadap suatu maslahat, kesenangan akhirat yang pasti dan baik, serta membersihkan diri dari segala dosa. Hal ini semata-mata dilakukan untuk mencari keridhaan Allah. Tarhib adalan ancaman yang diikuti siksaan sebagai akibat karena melakukan dosa. Tarhib dimaksukkan untuk memberikan rasa takut kepada hamba-Nya agar selalu berahtihati dalam melakukan sesuatu.

\section{f. Strategi Kedisiplinan}

Pendidikan yang disiplin membutuhkan ketekunan dan kebijaksanaan. Ketak berarti seorang pendidik harus menghukum setiap pelanggaran yang dilakukan oleh peserta didik, sedangkan kebijaksanaan mengharuskan seroang guru untuk menjatuhkan hukuman sesuai dengan sifat pelanggarannya, tanpa merasa terbebani oleh emosi atau dorongan lain. Ta'zir adalah hukuman yang dijatuhkan kepada siswa yang menyakiti diri sendiri. Sanksi ini berlaku bagi mereka yang berulang kali melanggar peringatan tanpa mengindahkan peringatan yang diberikan tersebut (Munif 2017, 7-9).

\section{g. Strategi Kekuasaan}

Strategi kekuasaan yaitu strategi penanaman agama dalam lembaga pendidikan melalui pelaksanaan kekuasaan atau melalui kekuasaan rakyat, dalam hal ini peran masyarakat dan lembaga pendidikan dengan segala dayanya sangat dominan dalam hal mengubah sesuatu.

\section{h. Strategi Persuasi}

Strategi persuasi yang dilakukan melalui pembentukan opini dan visi masyarakat atau warga lembaga pendidikan.

\section{i. Strategi Peraturan Pendidikan}

Strategi pertama dikembangkan melalui pendekatan perintah dan latrangan atau penghargaan dan sanksi. Sedangkan strategi kedua dan ketiga dikembangkan melalui pembiassan, keteladanan dan keyakinan atau secara halus mengajak warga serta mmberikan alasan dan perspektif yang baik yang dapat menyakinkan mereka (Mulyadi 2018, 6-7).

\section{KESIMPULAN}

Nilai adalah kualitas sesuatu yang membuatnya dihargai, diinginkan, dicari, berharga, berguna dan dapat meghidupkannya dengan bermartabat. Mujib dan Mudzakkir mengungkapkan nilai normative ajaran Islam yang terkandung dalam Al-Qur'an menjadi acuan dalam pendidikan Islam. Nata mengungkapkan kandungan nilai ajaran Islam meliputi aspek akidah, ibadah, dan akhlak. Adapun strategi yang digunakan dalam melaksanakan pembudayaan nilai-nila Islam baik di madrasah ataupun masyarakat adalah: strategi keteladanan, pembiasaan, ibrah dan amtsal, pemberian nasehat, pemberian janji dan ancaman, kedisiplinan, kekuasaan, persuasi, dan peraturan pendidikan.

\section{DAFTAR PUSTAKA}

Arifin, Samsul. T.T. "Pengembangan Budaya Religius Di Sekolah."

Harahap, Nursapia. 2014. "Penelitian Kepustakaan.” Jurnal Iqra' 8 (1).

Kholiq, Abdul. 2015. "Pendidikan Agama Islam Dalam Kebudayaan Masyarakat Kalang." Jurnal AtTaqaddum 7 (2). 
6425 Pembudayaan Nilai-Nilai Islam di Madrasah dan Masyarakat - Sedya Santosa, Tria Marvida DOI: https://doi.org/10.31004/basicedu.v5i6.1643

Mala, Abdurrahman R. 2015. "Membangun Budaya Islami Di Sekolah.” Irfani 11 (1): 13.

Mardia. 2017. "Penerapan Nilai-Nilai Ajaran Islam Dalam Pembelajaran Mata Pelajaran Umum Di Madrasah Tsanawiyah Negeri (Mtsn) Tinambung Kabupaten Polewali Mandar." Jurnal Pendidikan Islam: Pendekatan Interdesipliner 1 (2).

Ma'rufah, Afni. 2020. "Pengembangan Mata Pelajaran Pendidikan Agama Islam Dalam Mewujudkan Budaya Religius Di Sekolah.” Edukasia : Jurnal Pendidikan Dan Pembelajaran 1 (1).

Masriafatin, Yuni. 2019. "Strategi Pembudayaan Karakter Pada Pendidikan Dasar Islam." Jurnal Lentera: Kajian Keagamaan, Keilmuan Dan Teknologi 18 (1).

Muh. Fitrah, Dan Luthfiyah. 2017. Metodologi Penelitian; Penelitian Kualitatif, Tindakan Kelas \& Studi Kasus. Jawa Barat: Cv Jejak.

Muhsinin, Muhsinin. 2013. "Model Pendidikan Karakter Berbasis Nilai-Nilai Islam Untuk Membangun Karakter Siswa Yang Toleran.” Edukasia : Jurnal Penelitian Pendidikan Islam 8 (2).

Mulyadi, Edi. 2018. “Strategi Pengembangan Budaya Religius Di Madrasah.” Jurnal Kependidikan 6 (1).

Munif, Muhammad. 2017. "Strategi Internalisasi Nilai-Nilai Pai Dalam Membentuk Karakter Siswa." Edureligia; Jurnal Pendidikan Agama Islam 1 (2): 1-12.

. T.T. "Pengembangan Pendidikan Agama Islam Sebagai Budaya Sekolah.” Pedagogik: Jurnal Pendidikan 3 (2): 12.

Pairin. 2019. "Penanaman Nilai-Nilai Pendidikan Agama Islam Pada Peserta Didik Di Pesantren Ummusshabri Kota Kendari." Shautut Tarbiyah 25 (1).

Prasetyo, Donny Dan Irwansyah. 2020. "Memahami Masyarakat Dan Perspektifnya." Jurnal Manajemen Pendidikan Dan Ilmu Sosial 1 (1): 163-75.

Rizal, Syaiful. 2017. "Strategi Guru Kelas Dalam Menumbuhkan Nilai-Nilai Karakter Pada Siswa Sd/Mi.” Al Ibtida: Jurnal Pendidikan Guru Mi 4 (1).

Rizal, Syaiful, Dan Abdul Munip. 2017. "Strategi Guru Kelas Dalam Mumbuhkan Nilai-Nilai Karakter Pada Peserta Didik (Study Kasus : Sdn Pondok Dalem 01 Semboro Dan Mi Fathus Salafi Ajung Jember)." Al Ibtida: Jurnal Pendidikan Guru Mi 4 (1): 45.

Rosidah, Siti. 2019. "Nilai-Nilai Pendidikan Islam Dalam Budaya Sekolah Di Sdi Salafiyah Kahiruddin Gondanglegi." Skripsi, Malang: Uin Maulana Malik Ibrahim Malang.

Sari, Milya. 2020. "Penelitian Kepustakaan (Library Research) Dalam Penelitian Pendidikan Ipa." Natural Science: Jurnal Penelitian Bidang Ipa Dan Pendidikan Ipa, No. 1: 13.

Siswanto, Heru. 2019. "Pentingnya Pengembangan Budaya Religius Di Sekolah.” Madinah: Jurnal Studi Islam 6 (1).

Subianto, Jito. 2013. "Peran Keluarga, Sekolah, Dan Masyarakat Dalam Pembentukan Karakter Berkualitas." Edukasia : Jurnal Penelitian Pendidikan Islam 8 (2).

Talibo, Ishak. 2019. "Pendidikan Islam Dengan Nilai-Nilai Dan Budaya.” Jurnal Ilmiah Iqra' 13 (1): 48.

Wahyudi, Elvi. 2020. "Pembudayaan Nilai-Nilai Pendidikan Agama Islam Multikulturalpada Akademik Keperawatan Pemerintah Kabupaten Gresik." Pendidikan Multikultural 4 (2).

Zainuddin. 2019. "Menciptakan Budaya Religius Pada Madrasah.” El-Huda 10 (2).

Zed, Mestika. 2008. Metode Penelitian Kepustakaan. Ed. 2. Jakarta: Yayasan Obor Indonesia. 